\title{
BMJ Open Vitamin D status and associated metabolic risk factors among North Korean refugees in South Korea: a cross-sectional study
}

Kyeong Jin Kim, ${ }^{1}$ Yoon Jung Kim, ${ }^{2}$ Sun Hwa Kim, ${ }^{1}$ Jee Hyun An, ${ }^{1}$ Hye Jin Yoo, ${ }^{1}$ Hee Young Kim, ${ }^{1}$ Ji A Seo, ${ }^{1}$ Sin Gon Kim, ${ }^{1}$ Nan Hee Kim, ${ }^{1}$ Kyung Mook Choi, ${ }^{1}$ Sei Hyun Baik, ${ }^{1}$ Dong Seop Choi, ${ }^{1}$ Nam Hoon Kim ${ }^{1}$

To cite: Kim KJ, Kim YJ, Kim SH, et al. Vitamin D status and associated metabolic risk factors among North Korean refugees in South Korea: a crosssectional study. BMJ Open 2015;5:e009140. doi:10.1136/bmjopen-2015009140

- Prepublication history for this paper is available online. To view these files please visit the journal online (http://dx.doi.org/10.1136/ bmjopen-2015-009140).

KJK and YJK contributed equally.

Received 24 June 2015 Revised 30 October 2015 Accepted 2 November 2015

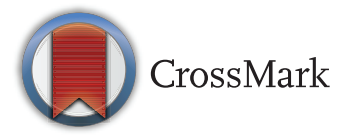

${ }^{1}$ Division of Endocrinology and Metabolism, Department of Internal Medicine, Korea University College of

Medicine, Seoul, Republic of Korea

${ }^{2}$ Division of Endocrinology and Metabolism, Department of Internal Medicine, Hallym University Kangdong Sacred Heart Hospital, Seoul, Republic of Korea

Correspondence to Dr Nam Hoon Kim; pourlife@naver.com

\section{ABSTRACT}

Objective: Vitamin $D$ deficiency is now recognised as a common health problem associated with various chronic diseases; however, it has not been fully elucidated among the minority groups. Here, we aimed to investigate the prevalence of vitamin $D$ deficiency and its associated metabolic risk factors among North Korean refugees living in South Korea.

Design: Cross-sectional analysis from the longitudinal cohort, the North Korean refugee health in South Korea (NORNS) study.

Participants: A total of 386 North Korean refugees aged $\geq 30$ years, who measured serum 25-hydroxy vitamin $D(25(\mathrm{OH}) \mathrm{D})$ level.

Results: The prevalence of vitamin $D$ deficiency $(25(\mathrm{OH}) \mathrm{D}<20 \mathrm{ng} / \mathrm{mL}$ ) was $87 \%$ and no participants had an adequate vitamin $D$ level $(25(\mathrm{OH}) \mathrm{D} \geq 30 \mathrm{ng} /$ $\mathrm{mL}$ ). Underweight participants (body mass index (BMI) $<18 \mathrm{~kg} / \mathrm{m}^{2}$ ) had significantly lower 25(OH)D levels than individuals with normal BMI $\left(\geq 18.5\right.$ and $\left.<23 \mathrm{~kg} / \mathrm{m}^{2}\right)$. In the multivariate logistic regression analysis, the lowest $25(\mathrm{OH}) \mathrm{D}$ level $(<10 \mathrm{ng} / \mathrm{mL})$ was significantly associated with metabolic syndrome $(0 \mathrm{R}, 6.37,95 \% \mathrm{Cl} 1.34$ to $30.3)$, high triglyceride $(\mathrm{OR}, 6.71,95 \% \mathrm{Cl} 1.75$ to 25.7), and low high-density lipoprotein (OR, 5.98, 95\% $\mathrm{Cl} 1.54$ to 23.2) compared with $25(\mathrm{OH}) \mathrm{D}$ levels

$\geq 20 \mathrm{ng} / \mathrm{mL}$ after adjusting for age, sex, season, length of residence in South Korea, physical activity and BMI. Conclusions: Vitamin $D$ deficiency is very common among North Korean refugees in South Korea. Despite their lower BMI, vitamin D deficiency was associated with metabolic syndrome in this population.

\section{INTRODUCTION}

Vitamin D deficiency, which is defined as a serum 25-hydroxy vitamin D $(25(\mathrm{OH}) \mathrm{D})$ level of less than $20 \mathrm{ng} / \mathrm{mL}$, has been a common health problem in modern society. ${ }^{1}$ Traditionally, vitamin D serves as an important factor for bone health and mineral metabolism. ${ }^{2}$ Recent growing evidence indicates that a low vitamin $\mathrm{D}$ status is also

\section{Strengths and limitations of this study}

- Informative data of minority population by a researcher-driven interview and formal health examination.

- Lack of causal relationship by cross-sectional analyses.

- Single measurement of serum 25-hydroxy vitamin D level.

closely associated with a variety of nonskeletal health problems, including infection, autoimmune disease, obesity and cardiometabolic diseases. ${ }^{3}{ }^{4}$ Several large epidemiological studies showed that the prevalence of vitamin $\mathrm{D}$ deficiency or insufficiency was high, ranging between $25 \%$ and $64 \% .^{5-7}$ In South Korea, the prevalence of vitamin D deficiency is also high. According to the Fourth Korea National Health and Nutrition Examination Survey (KNHANES IV) from 2008, the prevalence of a low vitamin D status, that is, less than $20 \mathrm{ng} / \mathrm{mL}$ of $25(\mathrm{OH})$ $\mathrm{D}$, was $47.3 \%$ in men and $64.5 \%$ in women. ${ }^{8}$

Vitamin D deficiency is prevalent and even more common among immigrant populations than in the general population. In a previous study, the prevalence of vitamin D deficiency was $60.0 \%$ in US immigrants from various countries. ${ }^{9}$ In an Australian study of 215 refugee children, $61 \%$ were found to have vitamin $\mathrm{D}$ insufficiency. ${ }^{10}$ However, owing to the heterogeneity of race, small sample size and lack of accurate health information, only a few studies have investigated the vitamin $\mathrm{D}$ status and associated health conditions among immigrants and refugees.

The Korean peninsula is the only divided country in the world. Since the division of Korea into south and north in 1945, differences in the socioeconomic status between 
the two countries have worsened. North Korea has been affected by poverty and hunger, whereas South Korea has been progressively westernised. During the past decades, the number of North Korean refugees (NKRs) has sharply increased up to approximately 24000 by September 2012. ${ }^{11}$ Even after entering South Korea, these immigrants have been faced with many problems in stern resettlement processes and need to adjust to new cultural and socioeconomic environments ${ }^{12}$; therefore, they are still at high risk for medical, nutritional and psychological diseases.

Since 2008, we have collected demographic and medical information of NKRs living in South Korea. First, we investigated the prevalence and determinants of vitamin D status in this population. Second, although the association between vitamin $\mathrm{D}$ deficiency and metabolic health consequences has been widely investigated in the general population, this has rarely been done in immigrant or minority groups. Therefore, we also evaluated whether vitamin D deficiency is associated with obesity and metabolic syndrome in this group.

\section{METHODS}

\section{Participants}

This study used the data from the NORNS (North Korea refugee health in South Korea) study, which aimed to assess the health and nutritional status of 30-81-year-old NKRs living in South Korea. From October 2008, 647 NKRs voluntarily participated in the first wave survey. They participated in a structured interview, physical examination and blood sampling at the first visit to the Korea University Anam hospital located in Seoul. Since 2012, a second follow-up survey (second wave) has been conducted among NKRs who participated in the first wave survey. The second wave survey aimed to chase the changes of health and nutritional condition after adaptation to the South Korean society of NKRs.

The serum 25(OH)D level was measured in 386 participants from the first cohort. The detailed protocol and methods of the NORNS study have been reported previously. ${ }^{13}$ Written informed consent was obtained from all participants, and this study was approved by the Institutional Review Board (IRB) of Korea University's Anam Hospital under IRB process No. ED08023.

\section{Questionnaire}

Information on general demographic data including age, sex, occupation, income, marital status, residence in North and South Korea, year of emigration from North Korea, year of entry into South Korea, and the length of residence in a third nation was included in the questionnaire. Information was obtained on medical conditions including hypertension, diabetes mellitus, dyslipidaemia, cancer, infectious disease, autoimmune disease, pulmonary disease, cardiovascular disease and medications prescribed to the participants. Information on health-related lifestyle was also obtained, including smoking (never, $<5$ packs of cigarette, or $\geq 5$ packs of cigarette in the lifetime), alcohol consumption (never drinkers and current drinkers) and the amount of physical activity performed recently (none, $<10 \mathrm{~h}$ per week, $\geq 10 \mathrm{~h}$ per week). All information in the questionnaire was self-reported.

\section{Anthropometric and biochemical measurements}

Anthropometric measurements including height, body weight and waist circumference were made after an overnight fast at the first visit. Body mass index (BMI) was calculated as weight in kilograms divided by height in metres squared. Data on height and body weight at the time of emigration from North Korea and entry into South Korea were self-reported. These data allowed us to calculate the body weight changes for each participant. Systolic and diastolic blood pressure was measured using an automatic blood pressure monitor (TM-2655P; Biospace, Japan).

For the measurement of the serum $25(\mathrm{OH}) \mathrm{D}$ level, blood samples were collected from each participant after overnight fasting. Blood samples were centrifuged, immediately refrigerated, and transported in cold storage to the Neodine Reference Laboratories in Seoul, Korea. Serum 25(OH)D levels were measured using a gamma counter (1470 WIZARD, Perkin-Elmer, Finland). We defined vitamin $\mathrm{D}$ deficiency as a serum $25(\mathrm{OH}) \mathrm{D}$ level of less than $20 \mathrm{ng} / \mathrm{mL}$, and vitamin $\mathrm{D}$ insufficiency as a $25(\mathrm{OH}) \mathrm{D}$ of $20-29 \mathrm{ng} / \mathrm{mL}^{3}{ }^{3} 14$

Serum total cholesterol, triglycerides, high-density lipoprotein (HDL) cholesterol and liver enzyme levels were measured using an enzymatic method with a chemistry analyser (TBA 200-FR; Toshiba, Japan). The plasma glucose level was measured using the glucose oxidase method.

Metabolic syndrome was defined according to the Adult Treatment Panel III of the National Cholesterol Education Program guidelines, ${ }^{15}$ modified in accordance with the WHO's proposed waist circumstance (WC) cut-off points for Asians. Participants who met three or more of the following criteria were considered as having metabolic syndrome: $\mathrm{WC} \geq 90 \mathrm{~cm}$ in men and $\geq 80 \mathrm{~cm}$ in women, serum triglyceride level $\geq 150 \mathrm{mg} / \mathrm{dL}$, HDL-cholesterol levels $<40 \mathrm{mg} / \mathrm{dL}$ in men and $<50 \mathrm{mg} /$ $\mathrm{dL}$ in women, impaired fasting glucose $\geq 100 \mathrm{mg} / \mathrm{dL}$ or antidiabetic treatment and blood pressure $\geq 130 /$ $85 \mathrm{~mm} \mathrm{Hg}$ or treatment for hypertension.

\section{Statistical analysis}

Data are presented as mean $\pm \mathrm{SD}$ or absolute number/ percentage. For non-normally distributed variables such as the triglyceride level, statistical analysis was performed after logarithmic transformation.

Baseline characteristics were compared between three groups after classification according to the vitamin $\mathrm{D}$ status (serum 25(OH)D level $<10 \mathrm{ng} / \mathrm{mL}, 10-20 \mathrm{ng} / \mathrm{mL}$, and $\geq 20 \mathrm{ng} / \mathrm{mL}$ ) using one-way ANOVA or $\chi^{2}$ test. For the investigation of the relationship between the vitamin $\mathrm{D}$ status and its associated factors, variables were categorised 
as follows: age was categorised into 10-year periods and BMI was classified as $<18.5, \geq 18.5$ to $<23, \geq 23$ to $<25$, and $\geq 25 \mathrm{~kg} / \mathrm{m}^{2}$. Seasons were categorised as spring (MarchMay), summer (June-August), fall (SeptemberNovember) and winter (December-February).

We performed multivariate logistic regression analyses to investigate the association between vitamin $\mathrm{D}$ status and metabolic syndrome. Since the mean serum 25 $(\mathrm{OH}) \mathrm{D}$ level was very low and no participants had an optimal $25(\mathrm{OH}) \mathrm{D}$ level $(\geq 30 \mathrm{ng} / \mathrm{mL})$, the participants were divided into three groups according to the vitamin D status: $<10,10-20$, and $20-30 \mathrm{ng} / \mathrm{mL}$. In this analysis, three models were applied for each outcome: model 1 (adjusted for age, sex and season), model 2 (model 1 plus length of residence in South Korea and physical activity), and model 3 (model 2 plus BMI).

A $p$ value of less than 0.05 was considered statistically significant. All statistical analyses were performed using SPSS software V.18.0 (SPSS Inc., Chicago, Illinois, USA).

\section{RESULTS}

Among the 386 NKRs evaluated, 82 (21.0\%) were men. The mean age of the participants was $43.7( \pm 10.6)$ years and the mean BMI was $22.7( \pm 2.7) \mathrm{kg} / \mathrm{m}^{2}$. The mean serum $25(\mathrm{OH}) \mathrm{D}$ level was $17.4( \pm 4.5) \mathrm{ng} / \mathrm{mL}$ in men and $15.0( \pm 4.3) \mathrm{ng} / \mathrm{mL}$ in women. Baseline characteristics according to the vitamin $\mathrm{D}$ status are presented in table 1 . In general, the group with the lowest $25(\mathrm{OH}) \mathrm{D}$ level $(<10 \mathrm{ng} / \mathrm{mL})$ had lower BMI, body weight and height than the groups with higher $25(\mathrm{OH}) \mathrm{D}$ levels. Metabolic parameters including blood pressure and lipid profile were comparable between the three groups.

\section{Prevalence of vitamin D deficiency and its associated factors}

Prevalence of low vitamin D was very high in NKRs. No one had a sufficient level of serum 25(OH)D ( $\geq 30 \mathrm{ng}$ / $\mathrm{mL}$ ) among men and women. Participants with serum $25(\mathrm{OH}) \mathrm{D}$ levels of $<10,10-20,20-30 \mathrm{ng} / \mathrm{mL}$ were $8.8 \%$, $73.5 \%$, and $12.3 \%$, respectively (table 1 ).

The proportion of participants with serum $25(\mathrm{OH}) \mathrm{D}$ levels of $<10,10-20$, and $>20 \mathrm{ng} / \mathrm{mL}$, stratified by 10 -year age groups and by sex, is described in table 2 . In men, the prevalence of vitamin D deficiency was lowest among the youngest age group (69.2\% of $30-39$ years) and tended to increase with age. However, in women, the prevalence of vitamin D deficiency was generally similar in all age groups.

Table 3 presents the prevalence of vitamin D deficiency according to season. As expected, this prevalence was lowest in the summer and highest in the winter for both sexes.

Association of vitamin D deficiency with metabolic syndrome and its components

Table 4 shows the relationship between BMI and serum $25(\mathrm{OH}) \mathrm{D}$ levels. Compared with the normal BMI group
(18.5 to $23.0 \mathrm{~kg} / \mathrm{m}^{2}$ ), underweight participants with BMI below $18.5 \mathrm{~kg} / \mathrm{m}^{2}$ had a significantly lower vitamin $\mathrm{D}$ level after adjusting for age, sex and season $(\mathrm{p}=0.036)$. However, the overweight (23.0 to $25.0 \mathrm{~kg} / \mathrm{m}^{2}$ of $\mathrm{BMI}$ ) and obese $\left(\geq 25.0 \mathrm{~kg} / \mathrm{m}^{2}\right.$ of BMI $)$ groups had similar serum $25(\mathrm{OH}) \mathrm{D}$ levels to the normal BMI group.

The association between vitamin $\mathrm{D}$ status and metabolic syndrome and its components was assessed using multivariate logistic regression analyses (table 5). Compared with the group with the highest $25(\mathrm{OH}) \mathrm{D}$ level $(20-30 \mathrm{ng} / \mathrm{mL})$, the group with the lowest $25(\mathrm{OH})$ D level $(<10 \mathrm{ng} / \mathrm{mL})$ was associated more with metabolic syndrome after adjusting for potential confounders including age, sex, season, length of residence in South Korea and amount of physical activity (model 2). Even after additionally adjusting for BMI (model 3), the group with the lowest vitamin $\mathrm{D}$ level had a significantly higher OR for metabolic syndrome (OR, 6.37, 95\% CI 1.34 to 30.33 ).

When the same analyses were applied to each metabolic syndrome component, the lowest $25(\mathrm{OH}) \mathrm{D}$ group was also associated with a significantly higher OR for high triglyceride (OR, 6.71, 95\% CI 1.75 to 25.68), and low HDL (OR, 5.98, 95\% CI 1.54 to 23.19) in model 3 . However, high blood pressure and waist circumference were not significantly associated with the extremely low vitamin D status. For participants with a serum $25(\mathrm{OH}) \mathrm{D}$ level between 10 and $20 \mathrm{ng} / \mathrm{mL}$, the OR for hyperglycaemia (or diabetes mellitus) was significantly increased.

\section{DISCUSSION}

This study clearly showed that a substantial number of NKRs in South Korea had vitamin D deficiency; the mean serum $25(\mathrm{OH}) \mathrm{D}$ level was $15.5 \mathrm{ng} / \mathrm{mL}$. Moreover, the prevalence of low vitamin D was $87 \%$, and no participants had an adequate vitamin D level among NKRs in this study. This high prevalence exceeds that of the general population, including South Koreans, and is comparable to that of older people who are assisted in nursing homes. ${ }^{16}{ }^{17}$ In a previous study comprising the general population in South Korea, ${ }^{8}$ the prevalence of vitamin D deficiency in participants older than 30 years was about $30-50 \%$ in men, and $50-70 \%$ in women, which was much lower than that among NKRs (87\%) in this study.

The major source of vitamin $\mathrm{D}$ is through synthesis by the skin from sunlight exposure. ${ }^{3}$ Vitamin D can also be obtained from a few dietary sources such as oily fish and fortified foods. North Korea is located in high latitudes; therefore, insufficient sunlight exposure may partially explain the low level of vitamin D among NKRs. Furthermore, North Korean workers generally wear long-sleeved shirts and broad-brimmed hats during work-hours except in summer, which limits vitamin D3 synthesis. However, their mean age of 43.7 years, lean body weight and predominantly physical labour activities do not fully explain the extremely low serum $25(\mathrm{OH}) \mathrm{D}$ levels. 
Table 1 Baseline characteristics according to the serum 25(OH)D level

\begin{tabular}{|c|c|c|c|c|c|}
\hline & Total & $\begin{array}{l}\text { 25(OH)D } \\
<10 \mathrm{ng} / \mathrm{mL}\end{array}$ & $\begin{array}{l}25(\mathrm{OH}) \mathrm{D} \\
<10-20 \mathrm{ng} / \mathrm{mL}\end{array}$ & $\begin{array}{l}25(\mathrm{OH}) \mathrm{D} \\
\geq 20 \mathrm{ng} / \mathrm{mL}\end{array}$ & p Value* \\
\hline $\mathrm{N}(\%)$ & $386(100)$ & $36(8.8)$ & $300(73.5)$ & $50(12.3)$ & \\
\hline Male participants (\%) & $82(21.0)$ & $4(11.1)$ & 59 (19.7) & 19 (38.0) & 0.004 \\
\hline Age (years) & $43.7 \pm 10.6$ & $47.2 \pm 11.1$ & $43.4 \pm 10.7$ & $42.8 \pm 9.7$ & 0.055 \\
\hline BMI $\left(\mathrm{kg} / \mathrm{m}^{2}\right)$ & $22.7 \pm 2.7$ & $22.0 \pm 2.5$ & $22.8 \pm 2.9$ & $22.3 \pm 1.9$ & 0.507 \\
\hline Body weight $(\mathrm{kg})$ & $55.7 \pm 8.3$ & $52.5 \pm 7.0$ & $56.0 \pm 8.6$ & $56.5 \pm 7.3$ & 0.025 \\
\hline Height $(\mathrm{cm})$ & $156.8 \pm 7.1$ & $154.7 \pm 5.8$ & $156.7 \pm 7.0$ & $158.5 \pm 8.5$ & 0.013 \\
\hline Waist circumference $(\mathrm{cm})$ & $78.7 \pm 8.1$ & $77.2 \pm 7.4$ & $79.0 \pm 8.5$ & $77.8 \pm 6.0$ & 0.751 \\
\hline Systolic blood pressure $(\mathrm{mm} \mathrm{Hg})$ & $117.9 \pm 16.9$ & $117.8 \pm 22.4$ & $118.5 \pm 16.2$ & $114.2 \pm 16.5$ & 0.337 \\
\hline Diastolic blood pressure $(\mathrm{mm} \mathrm{Hg})$ & $75.5 \pm 12.9$ & $78.2 \pm 16.0$ & $75.6 \pm 12.7$ & $73.2 \pm 11.4$ & 0.079 \\
\hline Glucose $(\mathrm{mg} / \mathrm{dL})$ & $93.1 \pm 11.2$ & $94.5 \pm 9.2$ & $92.9 \pm 11.7$ & $93.5 \pm 9.7$ & 0.683 \\
\hline Total cholesterol (mg/dL) & $176.7 \pm 35.3$ & $183.8 \pm 36.9$ & $174.1 \pm 36.5$ & $183.0 \pm 34.1$ & 0.916 \\
\hline $\mathrm{HDL}-\mathrm{C}(\mathrm{mg} / \mathrm{dL})$ & $53.3 \pm 12.0$ & $51.5 \pm 13.8$ & $55.5 \pm 36.9$ & $54.1 \pm 12.6$ & 0.724 \\
\hline Triglyceride (mg/dL) & $98.6 \pm 73.8$ & $100.8 \pm 48.7$ & $99.1 \pm 80.1$ & $94.4 \pm 45.3$ & 0.692 \\
\hline Hypertension & $118(31.5)$ & $12(33.3)$ & $97(33.1)$ & $9(19.6)$ & 0.179 \\
\hline Diabetes mellitus & $88(23.9)$ & $7(20.0)$ & $72(25.1)$ & 9 (19.6) & 0.610 \\
\hline Cardiovascular disease & $37(9.6)$ & $4(11.1)$ & $28(9.3)$ & $5(10.0)$ & 0.938 \\
\hline Season (month) & & & & & $<0.001$ \\
\hline Spring (3-5) & $94(24.4)$ & $14(38.9)$ & $74(24.7)$ & $6(12.0)$ & \\
\hline Summer (6-8) & $121(31.3)$ & $6(16.7)$ & $85(28.3$ & $30(60.0)$ & \\
\hline Fall $(9-11)$ & $129(34.4)$ & $13(36.1)$ & $103(34.3)$ & $13(26.0)$ & \\
\hline Winter (12-2) & $42(10.9)$ & $3(8.3)$ & $38(12.7)$ & $1(2.0)$ & \\
\hline Length of residence in South Korea (months) & & & & & 0.175 \\
\hline $1-12$ & $131(34.7)$ & 8 (22.2) & $107(36.4)$ & $16(33.3)$ & \\
\hline $13-24$ & $63(16.7)$ & $10(27.8)$ & $45(15.3)$ & $8(16.7)$ & \\
\hline $25-36$ & 47 (12.4) & $6(16.7)$ & $38(12.9)$ & $3(6.2)$ & \\
\hline $37-48$ & $25(6.6)$ & $2(5.6)$ & $22(7.5)$ & $1(2.1)$ & \\
\hline$\geq 49$ & $112(29.6)$ & $10(27.8)$ & $82(27.9)$ & $20(41.7)$ & \\
\hline Occupation (in North Korea) & & & & & 0.743 \\
\hline Manual labour & $150(42.9)$ & $15(44.1)$ & $116(42.8)$ & $19(42.2)$ & \\
\hline Agriculture & $22(6.7)$ & $4(11.8)$ & $15(5.5)$ & $3(6.7)$ & \\
\hline Sales and service, teacher, specialist & $101(28.9)$ & $6(17.6)$ & $82(30.3)$ & $13(28.9)$ & \\
\hline Soldier & $12(3.4)$ & $1(2.9)$ & $9(3.3)$ & $2(4.4)$ & \\
\hline Student & $11(3.1)$ & $0(0.0)$ & $10(3.7)$ & $1(2.2)$ & \\
\hline NAt & $54(15.4)$ & $8(23.5)$ & 39 (14.4) & $7(15.6)$ & \\
\hline \multicolumn{6}{|l|}{ Region (N) } \\
\hline Urban area & $189(66)$ & $18(62.1)$ & $149(65.9)$ & $22(66.7)$ & 0.910 \\
\hline Rural area & 99 (34) & $11(37.9)$ & 77 (34.1) & 11 (33.3) & \\
\hline \multicolumn{6}{|l|}{ Smoking } \\
\hline Never-smoker & $221(72.9)$ & $20(80.0)$ & $178(75.4)$ & $23(54.8)$ & 0.001 \\
\hline Ex-smoker & $33(10.9)$ & $2(8.0)$ & $28(11.9)$ & $3(7.1)$ & \\
\hline Current smoker & 49 (16.2) & $3(12.0)$ & $30(12.7)$ & $16(38.1)$ & \\
\hline Alcohol consumption & & & & & 0.127 \\
\hline Never or former & $120(33.5)$ & $15(46.9)$ & $95(34.1)$ & $10(21.3)$ & \\
\hline$<10$ ounces/month & $218(60.9)$ & $17(53.1)$ & $167(59.9)$ & $34(72.3)$ & \\
\hline$\geq 10$ ounces $/$ month & $20(5.6)$ & $0(0.0)$ & $17(6.1)$ & $3(6.4)$ & \\
\hline Physical activity & & & & & 0.089 \\
\hline Never & $196(72.1)$ & $21(84.0)$ & $152(72.4)$ & $23(62.2)$ & \\
\hline$<10 \mathrm{~h} /$ week & $27(9.9)$ & $1(4.0)$ & $18(8.6)$ & $8(21.6)$ & \\
\hline$\geq 10 \mathrm{~h} /$ week & 49 (18.0) & $3(12.0)$ & $40(19.0)$ & 6 (16.2) & \\
\hline
\end{tabular}

The difficult circumstances that NKRs had to face should be considered when considering them in the context of vitamin D deficiency. They had an extremely low economic status while living in North Korea. Most of them experienced severe famine between 1994 and $1998 .^{18}$ In addition, the failure of the healthcare system 
Table 2 Proportion of participants with serum 25-hydroxyvitamin D levels of $<10,10-20$ and $\geq 20 \mathrm{ng} / \mathrm{mL}$ stratified by 10 -year age groups

\begin{tabular}{|c|c|c|c|}
\hline & \multicolumn{3}{|l|}{ 25(OH)D } \\
\hline & $\begin{array}{l}<10 \\
\mathrm{ng} / \mathrm{mL}\end{array}$ & $\begin{array}{l}10-20 \\
\mathrm{ng} / \mathrm{mL}\end{array}$ & $\begin{array}{l}\geq 20 \\
\mathrm{ng} / \mathrm{mL}\end{array}$ \\
\hline \multicolumn{4}{|c|}{ Male (age groups), years } \\
\hline $30-39(n=26)$ & $1(3.8)$ & $17(65.4)$ & $8(30.8)$ \\
\hline $40-49(n=30)$ & $2(6.7)$ & $20(66.7)$ & $8(26.7)$ \\
\hline $50-59(n=9)$ & $1(11.1)$ & 8 (88.9) & 0 \\
\hline $60-69(n=13)$ & 0 & $10(76.9)$ & $3(23.1)$ \\
\hline$\geq 70(n=4)$ & 0 & $4(100)$ & 0 \\
\hline \multicolumn{4}{|c|}{ Female (age groups), years } \\
\hline $30-39(n=136)$ & $11(8.1)$ & $112(82.4)$ & $13(9.6)$ \\
\hline $40-49(n=98)$ & $9(9.2)$ & $78(79.6)$ & $11(11.2)$ \\
\hline $50-59(n=42)$ & $4(9.5)$ & $33(78.6)$ & 5 (11.9) \\
\hline $60-69(n=25)$ & $8(32.0)$ & $16(64.0)$ & $1(4.0)$ \\
\hline$\geq 70$ s $(n=3)$ & 0 & $2(66.7$ & $1(33.3)$ \\
\hline
\end{tabular}

can aggravate the poor nutritional status. Therefore, we speculate that the low vitamin D status among NKRs is mainly due to the poor nutritional and medical status, particularly during their youth.

Old age, winter season, residence in urban areas, and obesity are well-known risk factors for vitamin D deficiency. ${ }^{4} \quad{ }^{19}$ In our study, these traditional risk factors did not affect vitamin $\mathrm{D}$ status except season and being female. In particular, obese participants (BMI of $25 \mathrm{~kg}$ / $\mathrm{m}^{2}$ or greater) had higher mean $25(\mathrm{OH}) \mathrm{D}$ levels than normal BMI participants. In contrast, underweight participants (BMI less than $18.5 \mathrm{~kg} / \mathrm{m}^{2}$ ) had a significantly lower level of $25(\mathrm{OH}) \mathrm{D}$. Previous studies suggest that obesity causes vitamin $\mathrm{D}$ deficiency via vitamin sequestration into excess adipose tissue, ${ }^{20}$ and population-based studies corroborate the negative association between

\begin{tabular}{|c|c|c|c|}
\hline & \multicolumn{3}{|l|}{ 25(OH)D } \\
\hline & $\begin{array}{l}<10 \\
\mathrm{ng} / \mathrm{mL}\end{array}$ & $\begin{array}{l}10-20 \\
\mathrm{ng} / \mathrm{mL}\end{array}$ & $\begin{array}{l}\geq 20 \\
\mathrm{ng} / \mathrm{mL}\end{array}$ \\
\hline \multicolumn{4}{|l|}{ Male (season) } \\
\hline Spring $(n=15)$ & $1(6.7)$ & $13(86.7)$ & $1(6.7)$ \\
\hline Summer $(n=32)$ & $1(3.1)$ & 18 (56.3) & $13(40.6)$ \\
\hline Fall $(n=27)$ & $2(7.4)$ & $21(77.8)$ & $4(14.8)$ \\
\hline Winter $(n=8)$ & 0 & 7 (87.5) & $1(12.5)$ \\
\hline \multicolumn{4}{|l|}{ Female (season) } \\
\hline Spring $(n=79)$ & $13(16.5)$ & $61(77.2)$ & $5(6.3)$ \\
\hline Summer $(n=89)$ & $5(5.6)$ & 67 (75.3) & $17(19.1)$ \\
\hline Fall $(n=102)$ & $11(10.8)$ & $82(80.4)$ & $9(8.8)$ \\
\hline Winter $(n=34)$ & $3(32.0)$ & $31(91.2)$ & 0 \\
\hline
\end{tabular}

Table 4 Adjusted mean $( \pm S D)$ serum 25-hydroxy vitamin D $(25(\mathrm{OH}) \mathrm{D})$ levels according to BMI subgroups; (adjusted for age, sex and season).

\begin{tabular}{cll}
\hline & \multicolumn{2}{l}{$\begin{array}{l}\text { Mean } 25(\mathrm{OH}) \mathbf{D} \\
\text { level }(\mathbf{n g} / \mathbf{m L})\end{array}$} \\
\cline { 2 - 3 } BMI group $\left(\mathbf{k g} / \mathbf{m}^{2}\right)$ & $\mathbf{p}$ Value & \\
\hline$<18.5(\mathrm{n}=17)$ & $14.4 \pm 4.1$ & 0.04 \\
$18.5-23(\mathrm{n}=203)$ & $15.5 \pm 4.9$ & Reference \\
$23-25(\mathrm{n}=89)$ & $15.6 \pm 4.4$ & 0.54 \\
$\geq 25(\mathrm{n}=72)$ & $15.7 \pm 3.5$ & 0.91 \\
\hline BMI, body mass index. & &
\end{tabular}

BMI and 25(OH)D levels. ${ }^{21}$ The negative association was also observed in school-age children. ${ }^{22}$ However, a few studies involving a specific ethnic group showed that BMI did not affect the vitamin D status. ${ }^{23}$ In the present study, we hypothesise that BMI values reflect the nutritional status rather than the obesity status among NKRs. To clarify this hypothesis, we tested the effect of other obesity measures, including waist circumference and per cent body fat; however, these measures had no significant association with $25(\mathrm{OH}) \mathrm{D}$ levels. In contrast, height, which partially reflects the nutritional status in adolescence, was significantly correlated with $25(\mathrm{OH}) \mathrm{D}$ levels in a regression analysis ( $\beta$ coefficient, 0.162 , $\mathrm{p}=0.001$, data not presented in the context).

Furthermore, vitamin D deficiency, especially severe vitamin D deficiency $(25(\mathrm{OH}) \mathrm{D}<10 \mathrm{ng} / \mathrm{mL})$, was significantly associated with metabolic syndrome primarily via the increased likelihood of having high triglyceride and low HDL. A growing body of evidence suggests that vitamin $\mathrm{D}$ deficiency predicts the development of insulin resistance, metabolic syndrome and cardiovascular diseases. ${ }^{24}$ Vitamin D activity occurs through vitamin D receptors, which are abundantly expressed in various tissues, including the endothelium, vascular smooth muscle and myocardium. ${ }^{25}$ In addition, vitamin D deficiency and the associated secondary hyperparathyroidism also play a role in increasing the cardiovascular risk. ${ }^{26}$

We observed that low BMI was associated with low 25 $(\mathrm{OH}) \mathrm{D}$ levels among NKRs. This result indicates that vitamin D deficiency is strongly associated with metabolic derangement beyond obesity. This result may be due to several unidentified factors, such as low muscle mass (sarcopenia) or the thrifty phenotype hypothesis, which explains the association between poor fetal and infant growth and increased risk of impaired glucose tolerance and metabolic syndrome in adult life. ${ }^{27}$ However, our data partially supported this hypothesis.

This study has several limitations. The first limitation is its cross-sectional design, which limited the evaluation of the causal relationship between vitamin D status and metabolic syndrome. Second, this study was based on a single measurement of the serum $25(\mathrm{OH}) \mathrm{D}$ level; therefore, other factors, such as parathyroid hormone, serum 
Table 5 ORs for metabolic syndrome and its components according to serum 25(OH)D levels

\begin{tabular}{|c|c|c|c|}
\hline & \multicolumn{3}{|l|}{ 25(OH)D } \\
\hline & $\begin{array}{l}20-30 \mathrm{ng} / \mathrm{mL} \\
(\mathrm{n}=49)\end{array}$ & $\begin{array}{l}10-20 \mathrm{ng} / \mathrm{mL} \\
(\mathrm{n}=294)\end{array}$ & $\begin{array}{l}<10 \mathrm{ng} / \mathrm{mL} \\
(\mathrm{n}=36)\end{array}$ \\
\hline \multicolumn{4}{|c|}{ Metabolic syndrome } \\
\hline Model 1 & Reference & $1.72(0.74$ to 4.04$)$ & $2.30(0.77$ to 6.91$)$ \\
\hline Model 2 & Reference & 3.45 (0.97 to 12.23$)$ & $5.60(1.17$ to 26.88$)$ \\
\hline Model 3 & Reference & $3.00(0.85$ to 10.58$)$ & 6.37 (1.34 to 30.33$)$ \\
\hline \multicolumn{4}{|c|}{ High BP or HTN } \\
\hline Model 1 & Reference & $2.94(1.21$ to 7.19$)$ & 2.16 (0.67 to 6.97$)$ \\
\hline Model 2 & Reference & $2.40(0.51$ to 11.44$)$ & $3.23(0.96$ to 10.89$)$ \\
\hline Model 3 & Reference & 2.94 (0.88 to 9.88$)$ & 2.69 (0.58 to 12.60$)$ \\
\hline \multicolumn{4}{|c|}{ High serum glucose or DM } \\
\hline Model 1 & Reference & 1.52 (0.67 to 3.43$)$ & 0.99 (0.31 to 3.19$)$ \\
\hline Model 2 & Reference & 6.30 (1.63 to 24.32$)$ & $1.06(0.14$ to 7.77$)$ \\
\hline Model 3 & Reference & 6.03 (1.57 to 23.14$)$ & $1.15(0.16$ to 8.37$)$ \\
\hline \multicolumn{4}{|c|}{ Waist circumference } \\
\hline Model 1 & Reference & $1.40(0.61$ to 3.17$)$ & 1.01 (0.33 to 3.10$)$ \\
\hline Model 2 & Reference & 1.79 (0.53 to 5.98$)$ & $0.81(0.15$ to 4.36$)$ \\
\hline Model 3 & & & \\
\hline \multicolumn{4}{|c|}{ High triglyceride level } \\
\hline Model 1 & Reference & $1.51(0.73$ to 3.14$)$ & 3.65 (1.36 to 9.76$)$ \\
\hline Model 2 & Reference & $1.42(0.55$ to 3.68$)$ & $6.81(1.78$ to 26.07$)$ \\
\hline Model 3 & Reference & 1.44 (0.55 to 3.72$)$ & 6.71 (1.75 to 25.68$)$ \\
\hline \multicolumn{4}{|l|}{ Low HDL } \\
\hline Model 1 & Reference & 1.49 (0.77 to 2.89$)$ & 2.77 (1.09 to 7.02$)$ \\
\hline Model 2 & Reference & $1.89(0.75$ to 4.74$)$ & 6.00 (1.55 to 23.25$)$ \\
\hline Model 3 & Reference & 1.91 (0.76 to 4.80$)$ & 5.98 (1.54 to 23.19$)$ \\
\hline
\end{tabular}

calcium, glomerular filtration rate and vitamin D intake through diet and supplements, were not assessed.

In conclusion, vitamin D deficiency was very common among NKRs aged $\geq 30$ years living in South Korea, with a prevalence of $87 \%$. Despite their low BMI, the low 25 $(\mathrm{OH}) \mathrm{D}$ level was associated with metabolic syndrome in this population.

Further investigations are needed to compare the vitamin D status between NKRs in South Korea and matched South Koreans. In addition, the causal relationship between vitamin D deficiency and metabolic syndrome can be elucidated with a follow-up study.

Acknowledgements The authors thank all the North Korean refugees who participated in the NORNS study, as well as medical doctors, nurses and volunteers who willingly contributed to the health examinations of the North Korean refugees.

Contributors NHK participated in the design of the study and contributed to the analysis and interpretation of data. KJK and YJK analysed the data and interpretation, and wrote the first draft of the manuscripts. SGK contributed to the conception and design of the NORNS study. SHK contributed JHA and HYK contributed to the analysis and interpretation of data. HJY, JAS, NHK, KMC and SHB contributed to the interpretation of data and critical revision of the manuscript. DSC oversaw the study, provided clinical expertise and participated in revisions of the manuscript draft for intellectual content.

Funding This research received no specific grant from any funding agency in the public, commercial or not-for-profit sectors.
Competing interests None declared.

Patient consent Obtained.

Ethics approval All participants gave written informed consent to participate. This study was approved by the Institutional Review Board (IRB) of Korea University's Anam Hospital.

Provenance and peer review Not commissioned; externally peer reviewed.

Data sharing statement No additional data are available.

Open Access This is an Open Access article distributed in accordance with the Creative Commons Attribution Non Commercial (CC BY-NC 4.0) license, which permits others to distribute, remix, adapt, build upon this work noncommercially, and license their derivative works on different terms, provided the original work is properly cited and the use is non-commercial. See: http:// creativecommons.org/licenses/by-nc/4.0/

\section{REFERENCES}

1. Holick MF. High prevalence of vitamin D inadequacy and implications for health. Mayo Clin Proc 2006;81:353-73.

2. Reichel H, Koeffler HP, Norman AW. The role of the vitamin D endocrine system in health and disease. $N$ Engl J Med 1989;320:980-91

3. Holick MF. Vitamin D deficiency. N Engl J Med 2007;357:266-81.

4. Holick MF. Sunlight and vitamin D for bone health and prevention of autoimmune diseases, cancers, and cardiovascular disease. $\mathrm{Am} \mathrm{J}$ Clin Nutr 2004;80:1678S-88S.

5. Looker AC, Dawson-Hughes B, Calvo MS, et al. Serum 25-hydroxyvitamin $D$ status of adolescents and adults in two seasonal subpopulations from NHANES III. Bone 2002;30:771-7. 
6. Bakhtiyarova S, Lesnyak O, Kyznesova N, et al. Vitamin D status among patients with hip fracture and elderly control subjects in Yekaterinburg, Russia. Osteoporos Int 2006;17:441-6.

7. Lips $\mathrm{P}$, Hosking $\mathrm{D}$, Lippuner $\mathrm{K}$, et al. The prevalence of vitamin $\mathrm{D}$ inadequacy amongst women with osteoporosis: an international epidemiological investigation. J Intern Med 2006;260:245-54.

8. Choi HS, Oh HJ, Choi $\mathrm{H}$, et al. Vitamin D insufficiency in Koreagreater threat to younger generation: the Korea National Health and Nutrition Examination Survey (KNHANES) 2008. J Clin Endocrinol Metab 2011;96:643-51.

9. Campagna AM, Settgast AM, Walker PF, et al. Effect of country of origin, age, and body mass index on prevalence of vitamin D deficiency in a US immigrant and refugee population. Mayo Clin Proc 2013;88:31-7.

10. Sheikh M, Wang S, Pal A, et al. Vitamin D deficiency in refugee children from conflict zones. J Immigr Minor Health 2011;13: 87-93.

11. Ministry of Unification, Republic of Korea. Current status of North Korean refugees' resettlement. http://www.unikorea.go.kr.

12. Jeon WT, Yu SE, Cho YA, et al. Traumatic experiences and menta health of north korean refugees in South Korea. Psychiatry Investig 2008;5:213-20.

13. Lee YH, Lee WJ, Kim YJ, et al. North Korean refugee health in South Korea (NORNS) study: study design and methods. BMC Public Health 2012;12:172.

14. Holick MF, Binkley NC, Bischoff-Ferrari HA, et al. Evaluation, treatment, and prevention of vitamin D deficiency: an Endocrine Society Clinical Practice guideline. J Clin Endocrinol Metab 2011;96:1911-30.

15. Expert Panel on Detection, Evaluation, and Treatment of High Blood Cholesterol in Adults. Executive summary of the third report of the National Cholesterol Education Program (NCEP) expert panel on detection, evaluation, and treatment of high blood cholesterol in adults (Adult Treatment Panel III). JAMA 2001;285:2486-97.

16. Pilz S, Dobnig H, Tomaschitz A, et al. Low 25-hydroxyvitamin D is associated with increased mortality in female nursing home residents. J Clin Endocrinol Metab 2012;97:E653-7.

17. Bischoff-Ferrari HA, Can U, Staehelin HB, et al. Severe vitamin D deficiency in Swiss hip fracture patients. Bone 2008;42:597-602.

18. Goodkind D, West L. The North Korean famine and its demographic impact. Popul Dev Rev 2001;27:219-38.

19. Wortsman J, Matsuoka LY, Chen TC, et al. Decreased bioavailability of vitamin D in obesity. Am J Clin Nutr 2000;72:690-3.

20. Blum M, Dolnikowski G, Seyoum E, et al. Vitamin $\mathrm{D}(3)$ in fat tissue. Endocrine 2008;33:90-4.

21. Holick MF, Chen TC. Vitamin D deficiency: a worldwide problem with health consequences. Am J Clin Nutr 2008;87:1080S-6S.

22. Gilbert-Diamond D, Baylin A, Mora-Plazas M, et al. Vitamin D deficiency and anthropometric indicators of adiposity in school-aged children: a prospective study. Am J Clin Nutr 2010;92:1446-51.

23. Nesby-O'Dell S, Scanlon KS, Cogswell ME, et al. Hypovitaminosis D prevalence and determinants among African American and white women of reproductive age: third National Health and Nutrition Examination Survey, 1988-1994. Am J Clin Nutr 2002;76:187-92.

24. Lee $\mathrm{JH}$, O'Keefe $\mathrm{JH}$, Bell $\mathrm{D}$, et al. Vitamin $\mathrm{D}$ deficiency an important common, and easily treatable cardiovascular risk factor? J Am Coll Cardiol 2008;52:1949-56.

25. Wang TJ, Pencina MJ, Booth SL, et al. Vitamin D deficiency and risk of cardiovascular disease. Circulation 2008;117:503-11.

26. Soubassi LP, Chiras TC, Papadakis ED, et al. Incidence and risk factors of coronary heart disease in elderly patients on chronic hemodialysis. Int Urol Nephrol 2006;38:795-800.

27. Hales CN, Barker DJ. The thrifty phenotype hypothesis. Br Med Bull 2001;60:5-20. 